\title{
Mechanism and Distribution of Calcareous Interbeds in Songtao Uplift and Its Periphery of Qiongdongnan Basin
}

\author{
Peiyuan Zhu*, Li You, Qingtao Yuan, Jia Zhong, Aiqun Liu \\ Zhanjiang Branch of CNOOC Ltd., Zhanjiang, China \\ Email: *zhupy@cnooc.com.cn
}

How to cite this paper: Zhu, P.Y., You, L., Yuan, Q.T., Zhong, J. and Liu, A.Q. (2018) Mechanism and Distribution of Calcareous Interbeds in Songtao Uplift and Its Periphery of Qiongdongnan Basin. Open Journal of Marine Science, 8, 370-385. https://doi.org/10.4236/ojms.2018.83020

Received: April 17, 2018

Accepted: July 1, 2018

Published: July 4, 2018

Copyright (c) 2018 by authors and Scientific Research Publishing Inc. This work is licensed under the Creative Commons Attribution International License (CC BY 4.0).

http://creativecommons.org/licenses/by/4.0/

\begin{abstract}
Based on core and casting slice observation, well drilling and logging data, the source of carbonate materials, lithology together with electric properties, types, genesis mechanism and distribution of calcareous interbeds in Songtao uplift and its periphery of Qiongdongnan Basin have been thoroughly analyzed. Results show that typical features have been appeared from well logging curves, containing low gamma-ray, low acoustic travel time, low neutron value, high density, as well as bright white calcium nodules or bands in electrical imaging well-logging curves. Drilling results reveal that calcareous interbeds developed mostly in high position of paleostructures and their distribution was controlled by the combined effects of macroscopic and microscopic factors. Macroscopically, calcareous interbeds relate to paleogeomorphology together with the combination of sandstone and mudstone. They are also controlled microscopically by the source of carbonate cements and pore space. Under normal circumstances, with regard to the same sand, the closer to the mudstone and the thicker of mudstone, the more conducive to the formation of calcareous interlayer. Low compaction strength, high content of rigid particles, coarse grain size, well-sorted sandstone and large pore space during carbonate cementation are favorable for the development of calcareous interbeds.
\end{abstract}

\section{Keywords}

Calcareous Interbeds, Material Sources, Genetic Mechanism, Distribution Rules, Pore Space, The Songtao Uplift and Its Periphery

\section{Introduction}

Interlayers refer to impervious bed or low-permeability layer within the sand 
body ranging from a few centimeters to a few meters. The morphology and distribution of interlayers are not stable due to the change of the micro-facies or phase of sand bodies caused by transient and local water flow changes. Interlayer is divided into two types: muddy interlayer and physical interlayer. With the success of $S$ structure, it became the first potential commercial discovery in northern depression belt of Qiongdongnan Basin, but the widespread development of physical interlayers (mainly calcareous interlayers) in the area brought difficulties to the next exploration. Calcareous interlayers refer to tight sandstone with carbonate content over $10 \%$ formed inside sand body. As a seepage barrier of the reservoir, it increases the heterogeneity of the reservoir, resulting in the thinning of the effective reservoir and the deterioration of physical properties, which restrict the later exploration and development.

At present, domestic and foreign scholars focus on the identification of calcareous interlayers, as well as its qualitative evaluation, formation conditions and so on. On the source of calcareous material, Longstaff [1] [2] [3] [4] considers that the calcareous mainly comes from dissolution of feldspar and other aluminosilicates by diatomaceous organic acids and conversion of clay minerals. Xu Bei-mei [5] believes that the enrichment of calcium is closely linked with hydration of aluminosilicate minerals during early diagenetic stages and organic acidification. Huang Si-jing [6] [7] suggests that calcium is owing to atmospheric weak acid water infiltration caused by mineral dissolution. Shan Jing-fu indicates that [8] [9] the source of calcium is not only the sedimentary period but also the supergene and diagenetic stage. Based on the previous studies and sedimentary and geochemical methods, a detailed analysis of sources, characteristics, types, genesis and distribution of calcareous interlayers are provided in this paper. Meanwhile, the summary of main controlling factors and distribution are of great significance to improve the success rate of drilling.

\section{Geological Background}

The Qiongdongnan Basin is a Cenozoic fault subsidence basin along the continental margin in northern South China Sea, which is one of the largest offshore oil-rich gas basins in China. The basin is located between $17^{\circ} 00^{\prime} \mathrm{N}$ to $18^{\circ} 50^{\prime} \mathrm{N}$ and $108^{\circ} 51^{\prime} \mathrm{E}$ to $114^{\circ} 41^{\prime} \mathrm{E}$ with an area about $60,000 \mathrm{~km}^{2}$. The north-south dissimilitude is obvious and it can be divided into the northern depression belt (which can be subdivided into Yabei Sag, Songxi Sag and Songdong Sag from west to east), the central uplift belt (namely Yacheng uplift-Songtao uplift belt), the central depression belt (which can be further divided into Yanan Sag, Ledong Sag, Lingshui Sag, Songnan Sag and Baodao Sag) and the southern uplift belt. Qiongdongnan Basin is located in Southeast Asia and southwestern China, prevailing in the southwest humid monsoon. It is very beneficial to the growth of terrestrial ferns, spores and herbaceous higher plants in the early Oligocene. The tectonic evolution of this basin has already undergone the Paleogene rifting stage, the early post crack with thermal-deposition stage and the late post crack 
as well as accelerated sedimentation stage during Neogene [10] (Figure 1). Paleogene Lingtou Formation, Yacheng Formation, Lingshui Formation, Neogene Sanya Formation, Meishan Formation, Huangliu Formation and Yinggehai Formation develop from bottom to top. S structure is located in southwest of Songdong depression in Qiongdongnan Basin. The main target layer mainly develops shallow sea sand dam in the first member of Sanya Formation, whose upper part is thick mudstone intercalated with argillaceous fine sandstone together with sand-rich layers (mainly composed of calcareous fine sandstone, fine sandstone and argillaceous siltstone) in the middle part and muddy siltstone in the lower part [11] (Figure 2).

\section{Databases and Methods}

This study was focused on the first member of Sanya Formation in Songtao uplift and its periphery of Qiongdongnan Basin where most of calcareous interbeds are widely distributed. Consequently, most of the drilling for gas has taken place in this area producing core material, debris, sidewall coring, well logs and other exploration and production well data made available for this research. All these data was derived from more than 10 wells.

A rich and valuable supply of analytical laboratory data in early Miocene and late Oligocene were gained from CNOOC Energy Development and Engineering Co. Ltd., China University of Petroleum, Chengdu University, Yangtze University and Research Institute of Geology, Shengli Oilfield Co. Ltd., Sinopec, which include 334 thin section identification samples, 336 granularity analysis points, 412 reservoir porosity and permeability data points, 268 heavy mineral samples, 210 clay X-ray diffraction points, 151 rock pyrolysis samples, 53 reflectance of vitrinite measurement, 49 carbon and oxygen isotope determination, 17 nuclear magnetic resonance samples, 34 constant pressure mercury points, 26 water analysis data and 20 scanning electron microscopy observation and analysis.

Based on the above basic data, this study is mainly divided into the following five aspects: Above all, based on core observation, palaeontology analysis, well

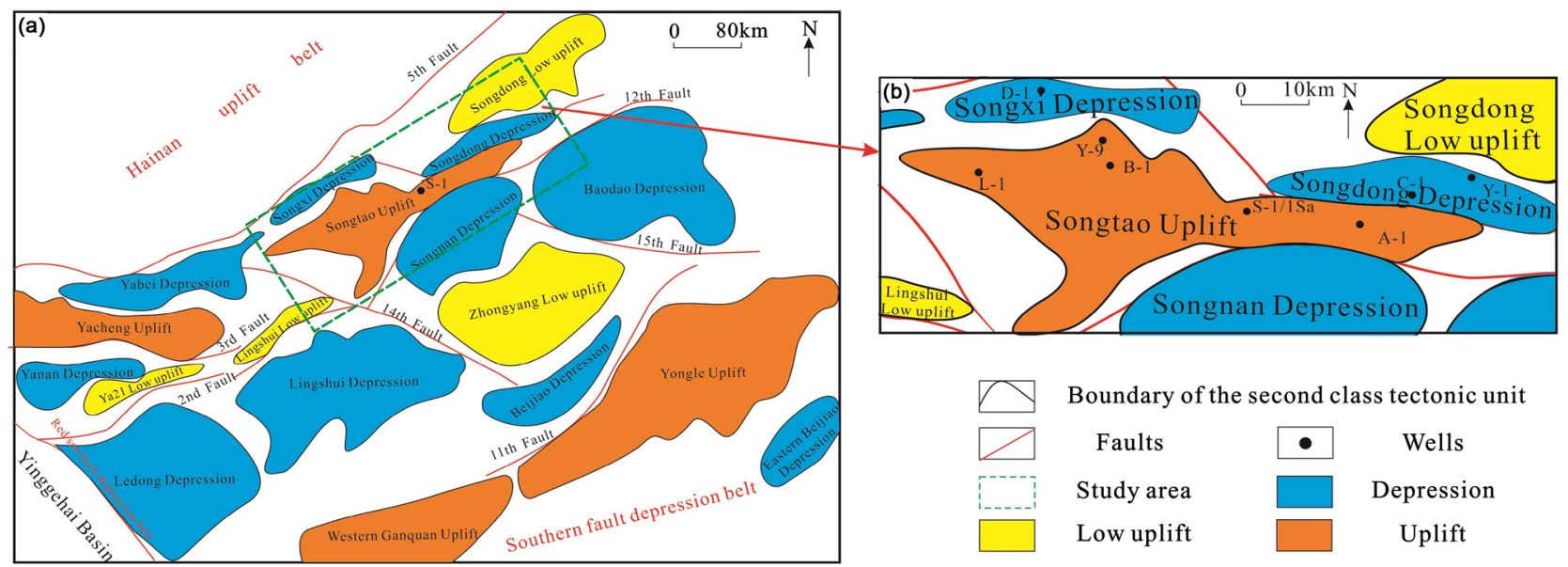

Figure 1. (a) Schematic configuration of the Qiongdongnan Basin; (b) The sub-tectonic units of the study area and well locations. 


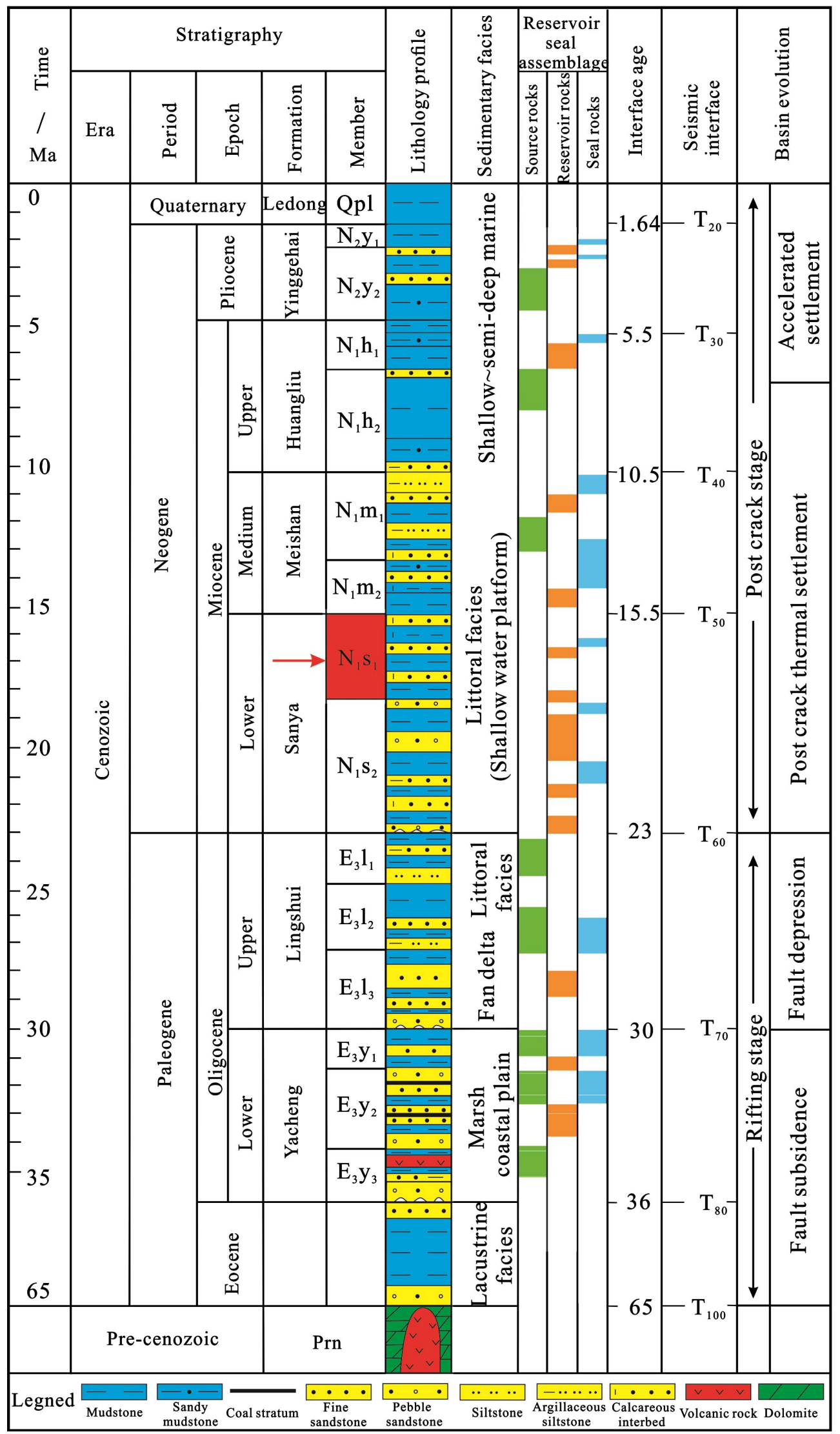

Figure 2. Generalized stratigraphy of the Qiongdongnan Basin. 
logging curve, seismic facies analysis as well as regional geological data, single-well facies, planar sedimentary facies and assemblages of sandstone and mudstone were sketched by making use of corelDRAWX6, ResForm and Gxplorer software. Secondly, based on the observation and identification of rock slices (using Laica4500p microscope and its image analysis techniques), scanning electron microscopy, constant pressure mercury injection, nuclear magnetic resonance, laser particle size, heavy minerals, whole rock analysis/clay X-ray diffraction and other data, the rock composition, structure and reservoir characteristics (reservoir space characteristics and pore throat types) were clearly identified. The importance of the combination of constant pressure mercury, nuclear magnetic resonance and capillary pressure is worth emphasizing. Among them, constant pressure mercury can reflect pore throat size together with quantity and has obvious advantages in quantitative evaluation of pore throat in low permeability reservoirs. Nuclear magnetic resonance is particularly suitable for the analysis of complex lithology, complex pore structure distribution, low porosity and low permeability reservoir. Combined with the capillary pressure curve can accurately characterize the microscopic pore throat structure characteristics of a comprehensive analysis of the parameters and its impact on reservoir physical properties. Thirdly, according to the percentage content of $S, R_{O}, T_{\max }$ and other parameters, the diagenetic stage were rigidly compartmentalized together with judging fluid properties; fourthly, the source of carbonate materials and the mechanism of calcareous interlayers were identified through the regional tectonic data, carbon and oxygen isotopes, water analysis. Last but not the least, characteristics, controlling factors and distribution of calcareous sandstone were summarized on account of comparison between calcareous interlayers and sandstone reservoirs in the target area.

\section{Results}

\subsection{Characteristics of the Calcareous Interbed}

\subsubsection{Lithology and Electric Properties}

The calcareous interbed in research area is mainly gray or gray-green calcareous cemented fine sandstone and medium sandstone, which not evenly distributes generally ranging from tens of centimeters to several meters, making bubbles in case of acid. Quartz and feldspar are main components of calcareous interbed with mean value of $55.8 \%$ quartz content, average value of $14 \%$ feldspar as well as $8.5 \%$ debris content. Calcareous interlayers are characterized by moderate structure maturity, mostly point or point-line contact relation, whose interstitial materials are mainly carbonate cements (ferrocalcite gives priority, followed by ferrodolomite and dolomite), usually in the form of strips, pyramids or polygons. The main type of porous cementation and filling replacement cementation are commonly found in the target area (Figure 3 ).

Through well logging analysis, calcareous interbeds have the following unique characteristics (Figure 4): 1) Low natural gamma (less than 80 API) and 


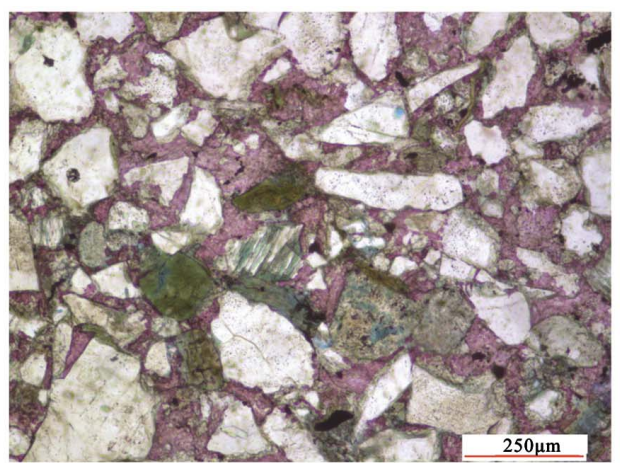

(a) $\mathrm{S}-1,2338 \mathrm{~m}$

Carbonate cement fills in pores or replace particles

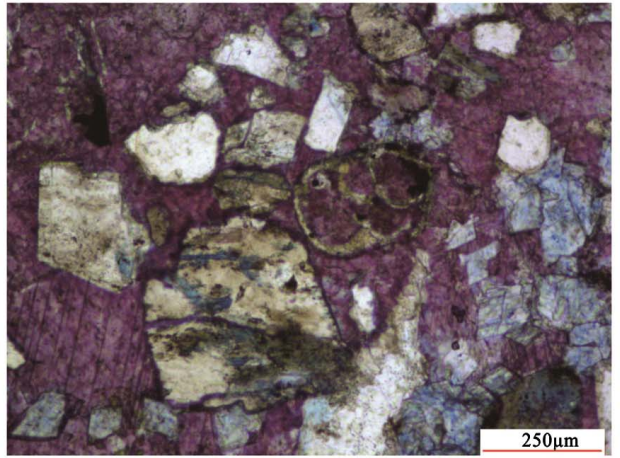

(c) B-1,3890m

Carbonate cement fills in pores or replace particles

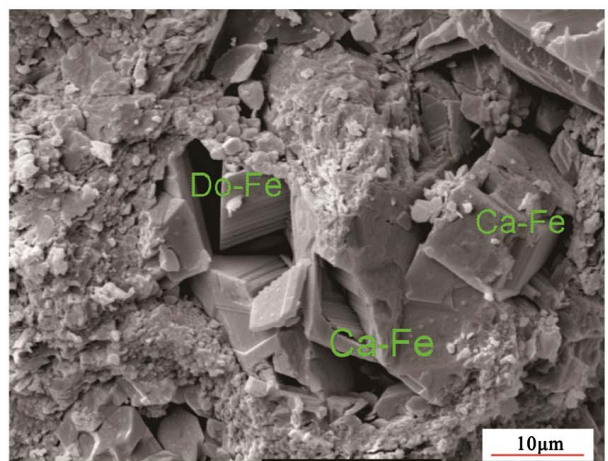

(b) $\mathrm{S}-1,2368.6 \mathrm{~m}$

Ankerite fills in intergranular pores

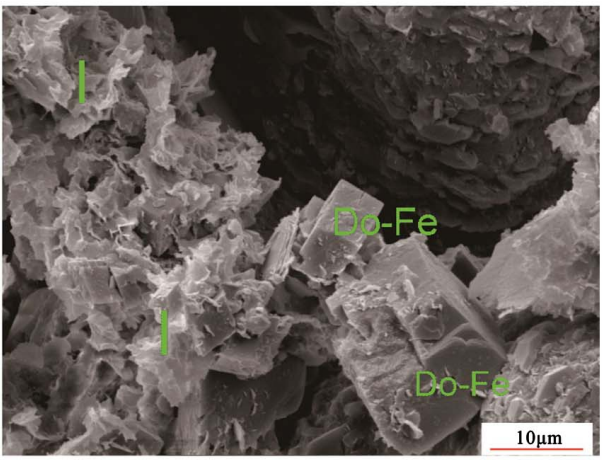

(d) $\mathrm{S}-1 \mathrm{Sa}, 2566.23 \mathrm{~m}$

Ferrocalcite and ankerite coexist and fill in intergranular pores

Figure 3. Casting slice observation of calcareous interbed (the magnification from (a) to (d) figures are 100, 930, 100, 1300 times the original size respectively).

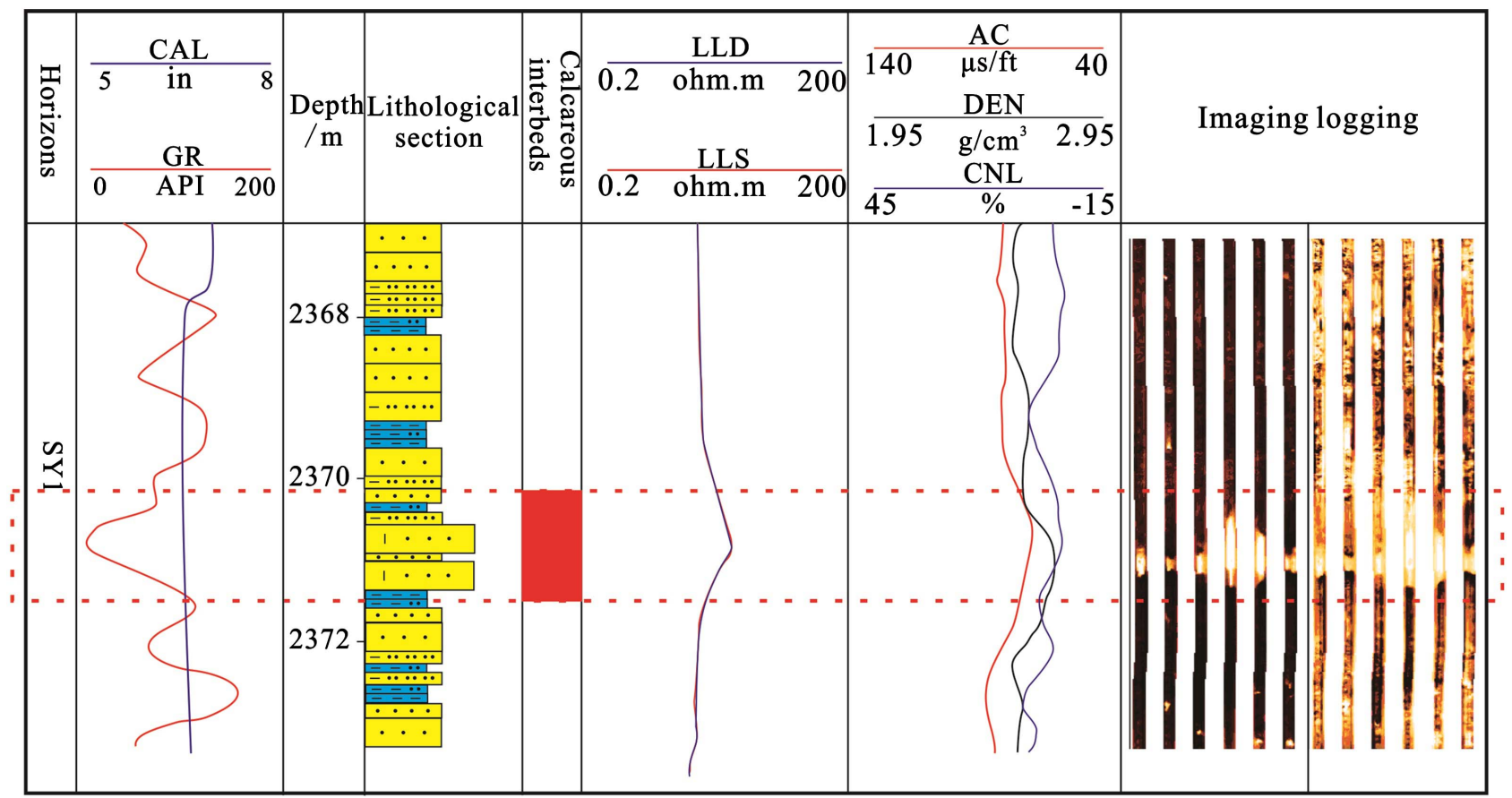

Figure 4. Typical logging response characteristics of calcareous interbed. 
no expanding diameter in the caliper curve 2) Higher lateral resistivity than any other sandstone sections 3) Obviously low interval transit time (generally below $75 \mu \mathrm{s} / \mathrm{ft}$, showing a "spike" in the negative direction) 4) High density (the average value is $2.62 \mathrm{~g} / \mathrm{cm}^{3}$ ) 5) Low neutron 6) Light yellow in electrical imaging logging performance with bright white calcium tuberculosis or bright white calcium band.

\subsubsection{Physical Characteristics}

There is a good negative correlation between the carbonate cement content and the actual porosity and permeability in the first member of the Sanya Formation in the target area (Figure 5). Calcareous cement is responsible for blocking pores and throats, the properties of calcareous interlayers tend to be significantly lower than those of other sandstone sections. Compared with other good-sorting sandstone reservoirs, calcareous interbed has smaller pore and throat radius with poorer distribution centralization and poorer reservoir properties (Figures 6-8). When the content of carbonate cements is less than $10 \%$, the porosity is more
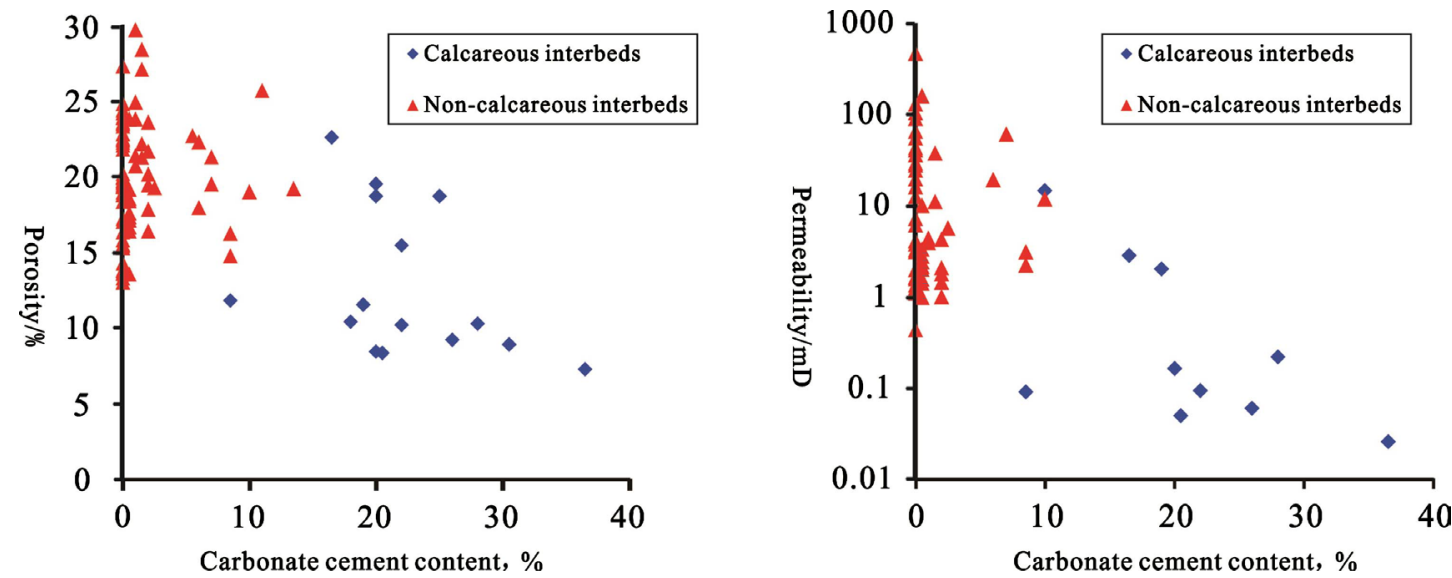

Figure 5. Relationship between physical properties and carbonate cement content (The functional relationship between porosity and carbonate cement content is $\mathrm{y}=20.783 \mathrm{e}^{-0.018 \mathrm{x}}, \mathrm{R}^{2}=0.7198$; the functional relationship between permeability and carbonate cement content is $\mathrm{y}=361.71 \mathrm{e}^{-0.432 \mathrm{x}}, \mathrm{R}^{2}=0.7624$.)
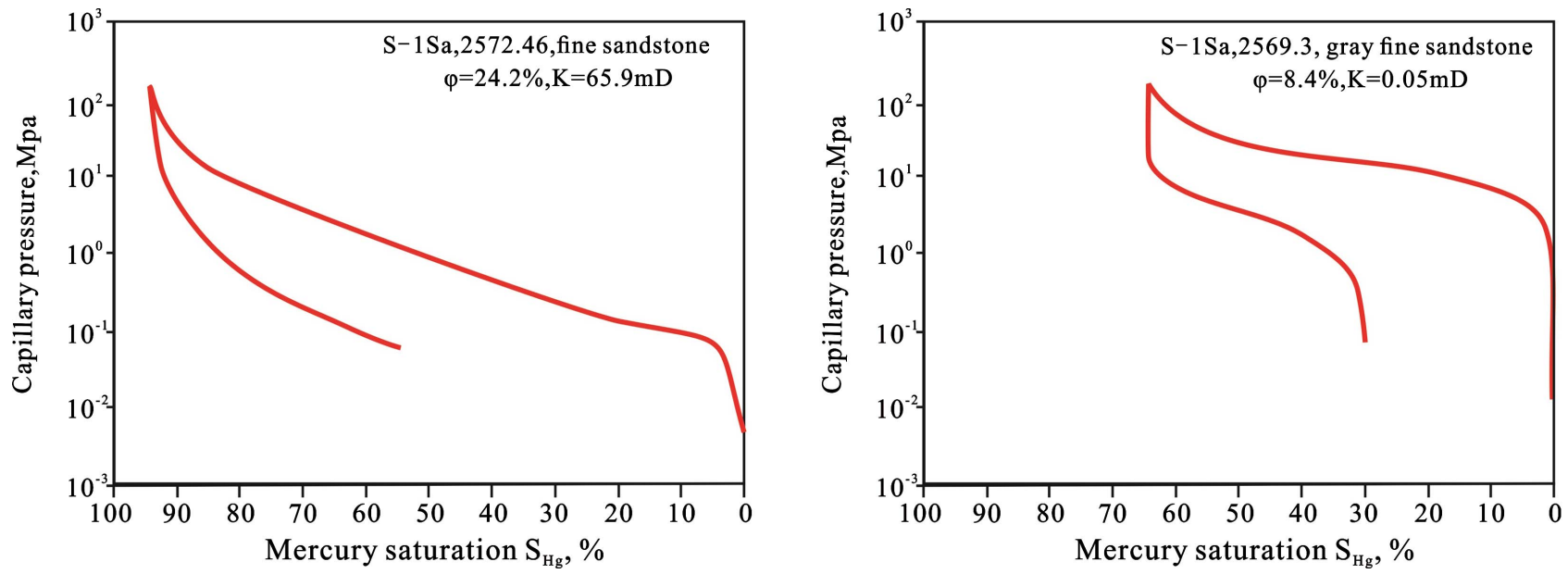

Figure 6. Capillary pressure curve comparation between calcareous interbed and sandstone reservoirs. 

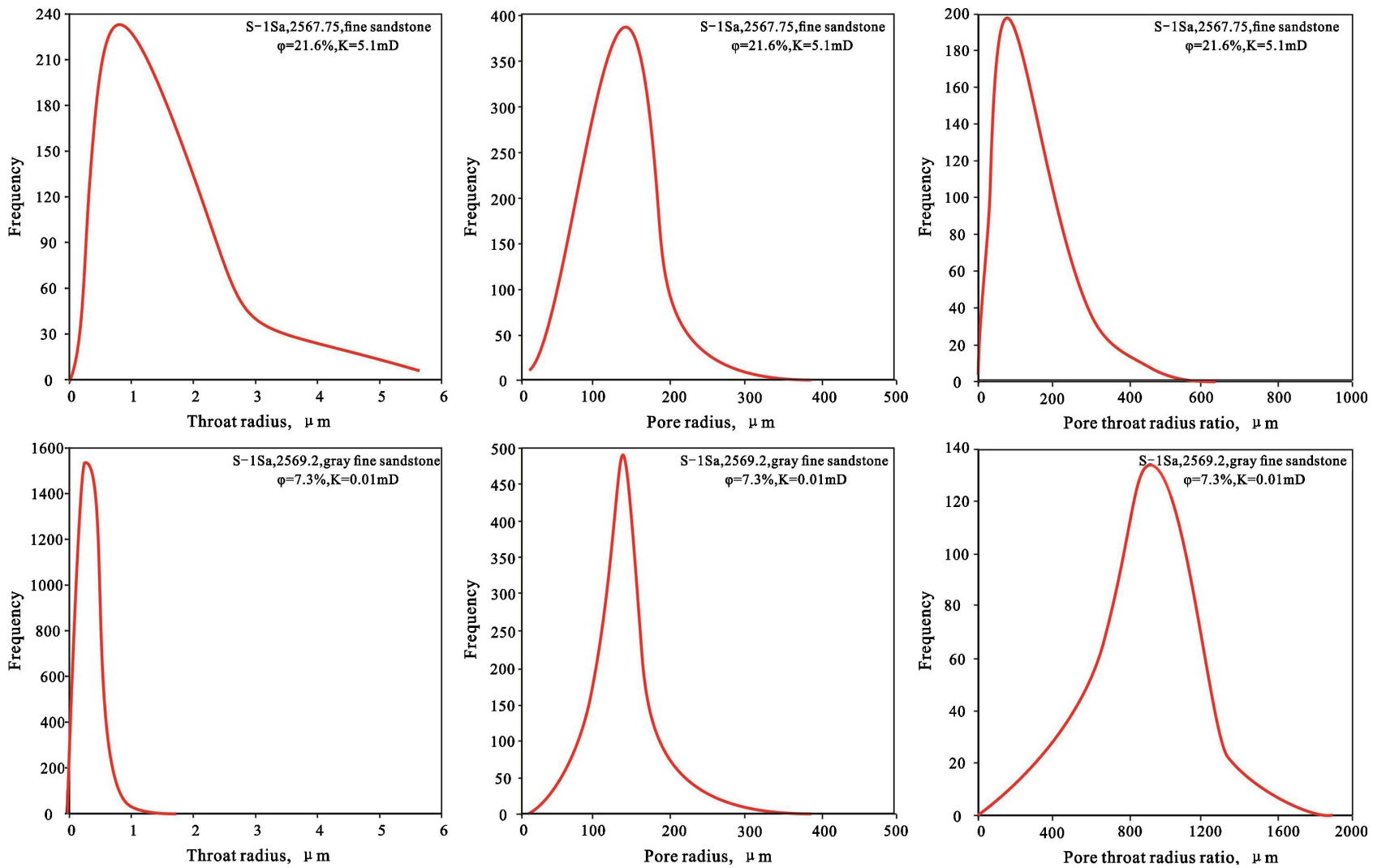

Figure 7. Pore and throat comparation between calcareous interbed and sandstone reservoirs in constant pressure mercury.
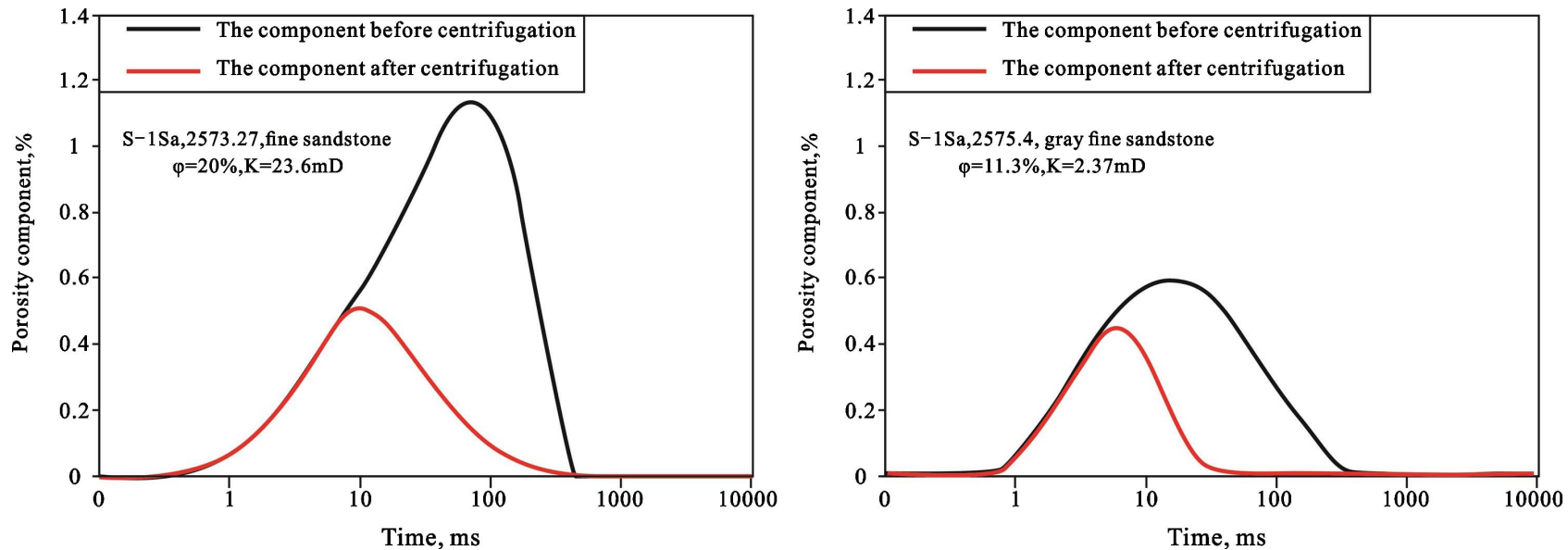

Figure 8. Pore and throat comparation between calcareous interbed and sandstone reservoirs in nuclear magnetic resonance.

than $15 \%$ with over $1 \times 10^{-3} \mu \mathrm{m}^{2}$ permeability. When the content is more than $10 \%$, the porosity is less than $15 \%$ and the permeability is under $1 \times 10^{-3} \mu^{2}$. In addition, the latter trend of reducing physical properties is slower than the former.

\subsection{Genetic Mechanism of the Calcareous Interbed}

Calcareous minerals (such as $\mathrm{Ca}^{2+}, \mathrm{Mg}^{2+}, \mathrm{HCO}_{3}^{-}$) is indispensable for the formation of calcareous interlayers, that is, it provides with both endogenous sub- 
stances and exogenous environment at the same time. The endogenous materials usually include the $\mathrm{Ca}^{2+}$ in the sedimentary water or pore water, the conversion from montmorillonite to illite in mudstone, the dissolution of carbonate minerals, the dissolution and alteration of feldspar, the corrosion of iron-rich and magnesium minerals (such as mica) and so on. Exogenous environments include atmospheric water, stratigraphic water moving along faults, clay dewatering and acidic water formed by the evolution of organic matter [12] [13] [14].

The stronger the diagenesis experienced by the rock, the lower the value of $\delta^{13} \mathrm{C}$, and the measured $\delta^{18} \mathrm{O}$ deviates greatly from the actual sedimentation value, so it is necessary to carry out "chronological effect" correction. According to the difference between the mean values of modern ocean carbonate $\delta^{18} \mathrm{O}$ and Miocene $\delta^{18} \mathrm{O}$, the Miocene limestone was corrected for "chronological effects", and then corrected temperature was calculated by $\delta^{18} \mathrm{O}$. On account of the analysis of carbon and oxygen isotope, the empirical formula $\mathrm{Z}=2.048 \times\left(\delta^{13} \mathrm{C}+50\right)$ $+0.498 \times\left(\delta^{18} \mathrm{O}+50\right)[15]$ [16] [17] shows that the $\mathrm{Z}$ value of the target area is less than 120, namely the pore fluid that forms carbonate cements is related to freshwater sedimentary environment, indicating that the cements are mainly carbonate related to organic components during diagenesis (Table 1).

The data show that there are mainly three water types $\left(\mathrm{NaHCO}_{3}, \mathrm{MgCl}_{2}\right.$ and $\mathrm{Na}_{2} \mathrm{SO}_{4}$ ) all related to the deep faults [18], resulting in $\mathrm{CO}_{2}$ getting into the formation water (Table 2 ). $\mathrm{CO}_{2}$ makes the following reaction carry on continuously: $\mathrm{CO}_{2}+\mathrm{H}_{2} \mathrm{O} \rightleftharpoons \mathrm{H}^{+}+\mathrm{HCO}_{3}^{-}(1), \mathrm{HCO}_{3}^{-} \rightleftharpoons \mathrm{H}^{+}+\mathrm{CO}_{3}^{2-}$ (2), $\mathrm{CO}_{2}+\mathrm{H}_{2} \mathrm{O} \rightleftharpoons \mathrm{H}^{+}$ $+\mathrm{CO}_{3}^{2-}$ (3). The combination of $\mathrm{CO}_{3}^{2-}\left(\mathrm{HCO}_{3}^{-}\right)$and $\mathrm{Ca}^{2+}\left(\mathrm{Mg}^{2+}\right)$ contribute to the formation of carbonate Cement. For example, the $\mathrm{CO}_{2}$ content of the S-1 well (mean $0.68 \%$ ) is lower than that of the S-1Sa well (mean $1.63 \%$ ), and the thickness of the former calcareous interlayers $(3.78 \mathrm{~m})$ is also lower than the latter $(17.6 \mathrm{~m})$, which is consistent with the above analysis [19].

Generally speaking, carbonate cements are divided into three genetic types. The meaning of I, II, III are diagenetic carbonate, biogas-related carbonate, and decarboxylation of organic acid associated carbonate representatively. There are two genetic types of calcareous interbed in target area: Type I and type III [20]

Table 1. Carbon and oxygen isotopes and temperature statistics.

\begin{tabular}{|c|c|c|c|c|c|c|c|c|c|}
\hline \multirow{2}{*}{ Well Horizon } & \multirow{2}{*}{ Lithology } & \multirow{2}{*}{$\begin{array}{c}\text { Depth } \\
\text { (m) }\end{array}$} & $\delta^{13} \mathrm{C}_{\mathrm{PDB}}$ & $\delta^{18} \mathrm{O}_{\mathrm{PDB}}$ & $\delta^{13} \mathrm{C}_{\mathrm{PDB}}$ calibration & $\delta^{18} \mathrm{O}_{\mathrm{PDB}}$ calibration & \multirow{2}{*}{$\begin{array}{c}\text { Temperature } \\
\left({ }^{\circ} \mathrm{C}\right)\end{array}$} & \multirow{2}{*}{$\begin{array}{c}\text { Corrected } \\
\text { temperature } \\
\left({ }^{\circ} \mathrm{C}\right)\end{array}$} & \multirow{2}{*}{$\mathrm{Z}$ value } \\
\hline & & & & & $(\%)$ & & & & \\
\hline \multirow{5}{*}{$\mathrm{C}-1$} & Calcareous mudstone & 2824 & -19.26 & -4.23 & -20.76 & -1.63 & 35.8 & 23 & 85.7 \\
\hline & Biological limestone & 2826 & -5.02 & -3.43 & -6.52 & -0.83 & 31.7 & 19.4 & 115.3 \\
\hline & Calcareous fine & 2826 & -10.5 & -5.09 & -12 & -2.49 & 40.3 & 27.1 & 103.3 \\
\hline & sandstone & 2830 & -20.39 & -1.86 & -21.89 & 0.74 & 24.1 & 12.6 & 84.6 \\
\hline & Biological limestone & 2830 & -6.89 & -5.71 & -8.39 & -3.11 & 43.7 & 30.1 & 110.3 \\
\hline \multirow[b]{2}{*}{ SY2 } & Calcareous mudstone & 2862 & -9.74 & -10.02 & -11.24 & -7.42 & 69.1 & 53.3 & 102.4 \\
\hline & $\begin{array}{l}\text { Calcareous fine } \\
\text { sandstone }\end{array}$ & 3232 & -1.73 & -8.77 & -3.23 & -6.17 & 61.4 & 46.2 & 119.4 \\
\hline
\end{tabular}


Table 2. Water analysis statistics of the target area.

\begin{tabular}{cccccccccccc}
\hline Well & Depth, m & Horizon & $\mathrm{PH}$ & $\begin{array}{c}\mathrm{K}^{+}+\mathrm{Na}^{+}, \\
\mathrm{mg} / \mathrm{L}\end{array}$ & $\begin{array}{c}\mathrm{Ca}^{2+}, \\
\mathrm{mg} / \mathrm{L}\end{array}$ & $\begin{array}{c}\mathrm{Mg}^{2+}, \\
\mathrm{mg} / \mathrm{L}\end{array}$ & $\begin{array}{c}\mathrm{CO}_{3}^{2-}, \\
\mathrm{mg} / \mathrm{L}\end{array}$ & $\begin{array}{c}\mathrm{HCO}_{3}^{-}, \\
\mathrm{mg} / \mathrm{L}\end{array}$ & $\begin{array}{c}\text { Total minerality, } \\
\mathrm{mg} / \mathrm{L}\end{array}$ & $\begin{array}{c}\text { Water } \\
\text { type }\end{array}$ & $\begin{array}{c}\text { Distance of main target } \\
\text { layer from faults, km }\end{array}$ \\
\hline $\mathrm{L}-1$ & 2677 & LS1 & 7.5 & 14257 & 58 & 0 & 33 & 940 & 37,531 & $\mathrm{NaHCO}_{3}$ & 1.8 \\
$\mathrm{~B}-1$ & 2141 & $\mathrm{SY} 1$ & 6.52 & 12075 & 144 & 86 & 0 & 2441 & 32,563 & $\mathrm{NaHCO}_{3}$ & 1.1 \\
Y9 & 2515 & LS3 & 7 & 4822 & 274 & 408 & 16 & 612 & 15,055 & $\mathrm{MgCl}_{2}$ & \\
Y9 & 2508 & LS3 & 6.4 & 110.19 & 548 & 1150.81 & 0 & 169 & 34,727 & $\mathrm{MgCl}_{2}$ & 0.28 \\
Y9 & 2509 & LS3 & 6.4 & 11090 & 548 & 1147.89 & 0 & 145 & 34,896 & $\mathrm{MgCl}_{2}$ & \\
Y9 & 2600 & LS3 & 6.4 & 11000 & 567 & 1144.35 & 0 & 169 & 34,705 & $\mathrm{MgCl}_{2}$ & \\
S-1Sa & 2301.8 & SY1 & 8.10 & 17179 & 388 & 512 & 12 & 1712 & 48,020 & $\mathrm{Na}_{2} \mathrm{SO}_{4}$ & \\
S-1Sa & 2311.6 & SY1 & 8.14 & 17603 & 365 & 452 & 15 & 1481 & 48,689 & $\mathrm{Na}_{2} \mathrm{SO}_{4}$ & 0.9 \\
\hline
\end{tabular}

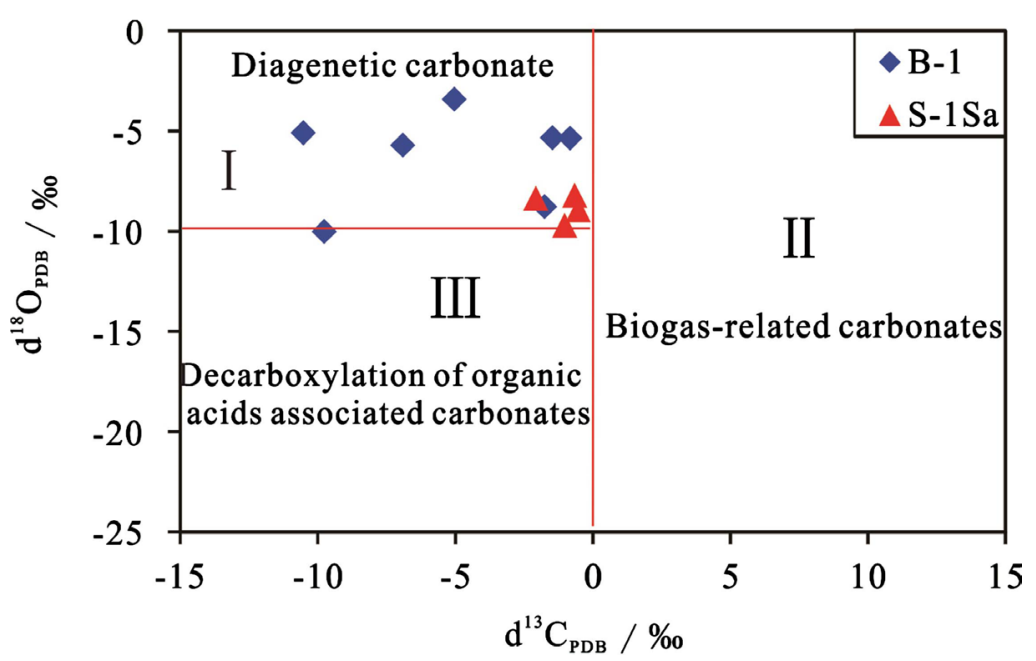

Figure 9. Carbon and oxygen isotopes characteristics of carbonate cements.

[21] [22] [23] [24] (Figure 9). Among them, Type I is formed by the integration of $\mathrm{Ca}^{2+}$ with $\mathrm{CO}_{3}^{2-}$ (calcium debris sediments transformed by fresh water) during the shallow burial stage, usually filling in the primary intergranular pores. While under deep burial conditions, the maturation of organic matter releases a large amount of organic acids, which facilitates the precipitation of calcium carbonate again by increasing the dissolution of carbonate and $\mathrm{pH}$ of the fluid, then type III comes into being. It's mainly found in interparticle or intragranular dissolved pores or replacing other particles (such as feldspar). Therefore, various sources of material for carbonate cements and continuous alternating of porous water are essential requirements to the continuation of the reaction.

\section{Discussion}

Since the strong randomness of calcareous interbed distribution, it's affected by the combination of multiple factors, mainly divided into macro and micro perspective. 
Macroscopically, the calcareous intercalations in the target area have poor lateral continuity, large thickness variation and closely related to sedimentary microfacies. However, the distribution of calcareous interbeds in different parts of the same genetic sand body varies with types of rock combination. There are four common types of calcareous interbeds as follows: the bottom type, the top type, the central type and the complete type [25] [26] [27] [28] [29]. Among them, the bottom type is mostly formed in the lower part of positive cyclic sandbody. The top type developed on the top of the anti-cyclic sandbody or distal bar, when the deposition is relatively stable. The central type calcareous interbed can be seen in underwater distributary channel or estuary dam owing to sand bodies vertically superimposed. The complete type calcareous interlayer is those isolated thin sand layer wrapped in mudstone, the entire sand was completely cemented by carbonate (Figure 10). In general, the bottom type calcareous interbed develops with large thickness, while others widely distribute with low thickness.

Microscopically, the distribution of calcareous interbed is controlled by the source of material and pore space during carbonate cementation. The former is influenced by mudstone thickness and the distance between sandstone and mudstone [30] [31] [32]. For the same sand layer, the greater thickness of mudstone, the closer to the sand body, the more abundant of the source, the more favorable to the formation of the calcareous interlayer. The latter is closely related to the petrological characteristics of the sand body and later diagenetic evolution. The high rigid content, coarse grain size and well-sorted sandstones which have good primary porosity and strong anti-compaction ability are prone to the formation of calcareous interlayers (Figure 11 \& Figure 12).

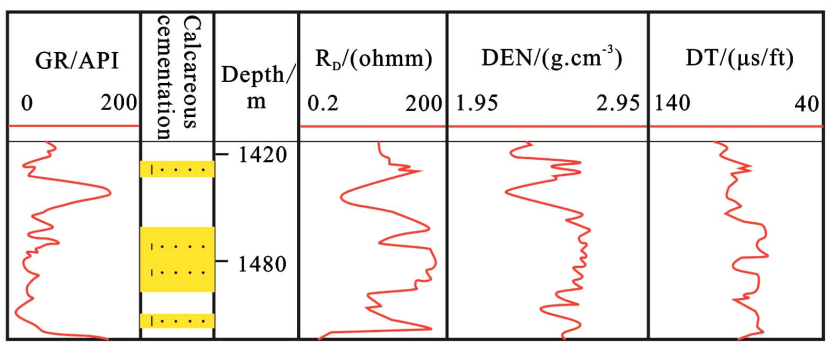

a- Bottom type ( $\mathrm{A}-1$ well)

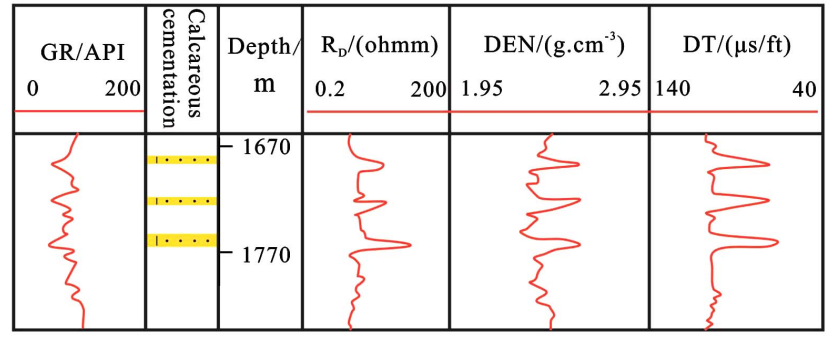

c - Central type ( $\mathrm{L}-1$ well )

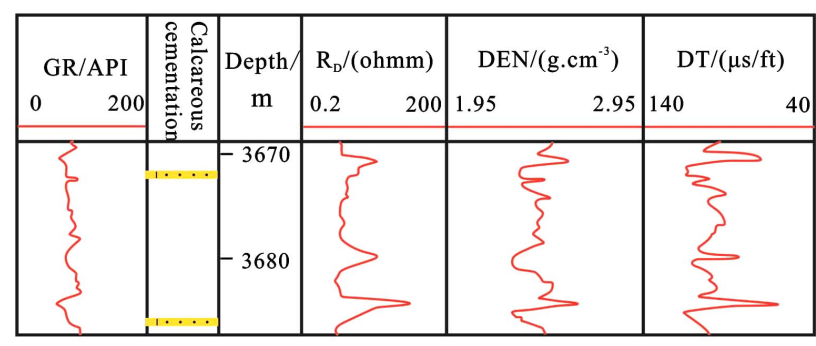

b-Top type ( $\mathrm{S}-1 \mathrm{Sa}$ well)

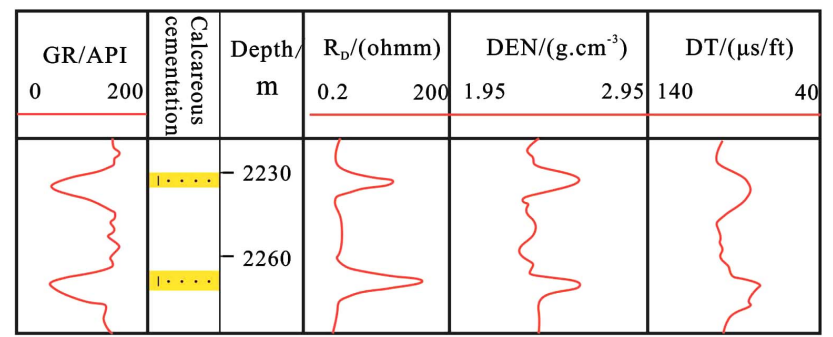

d-Complete type ( $\mathrm{Y}-9$ well $)$

Figure 10. Profile distribution type of calcareous interbed. 

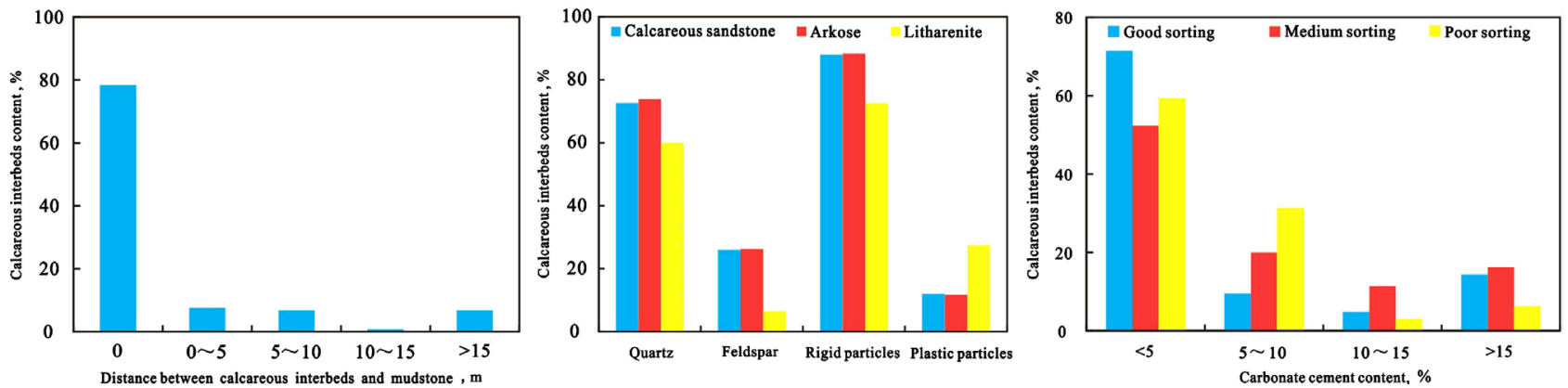

Figure 11. The controlling factor analysis of calcareous interbed.
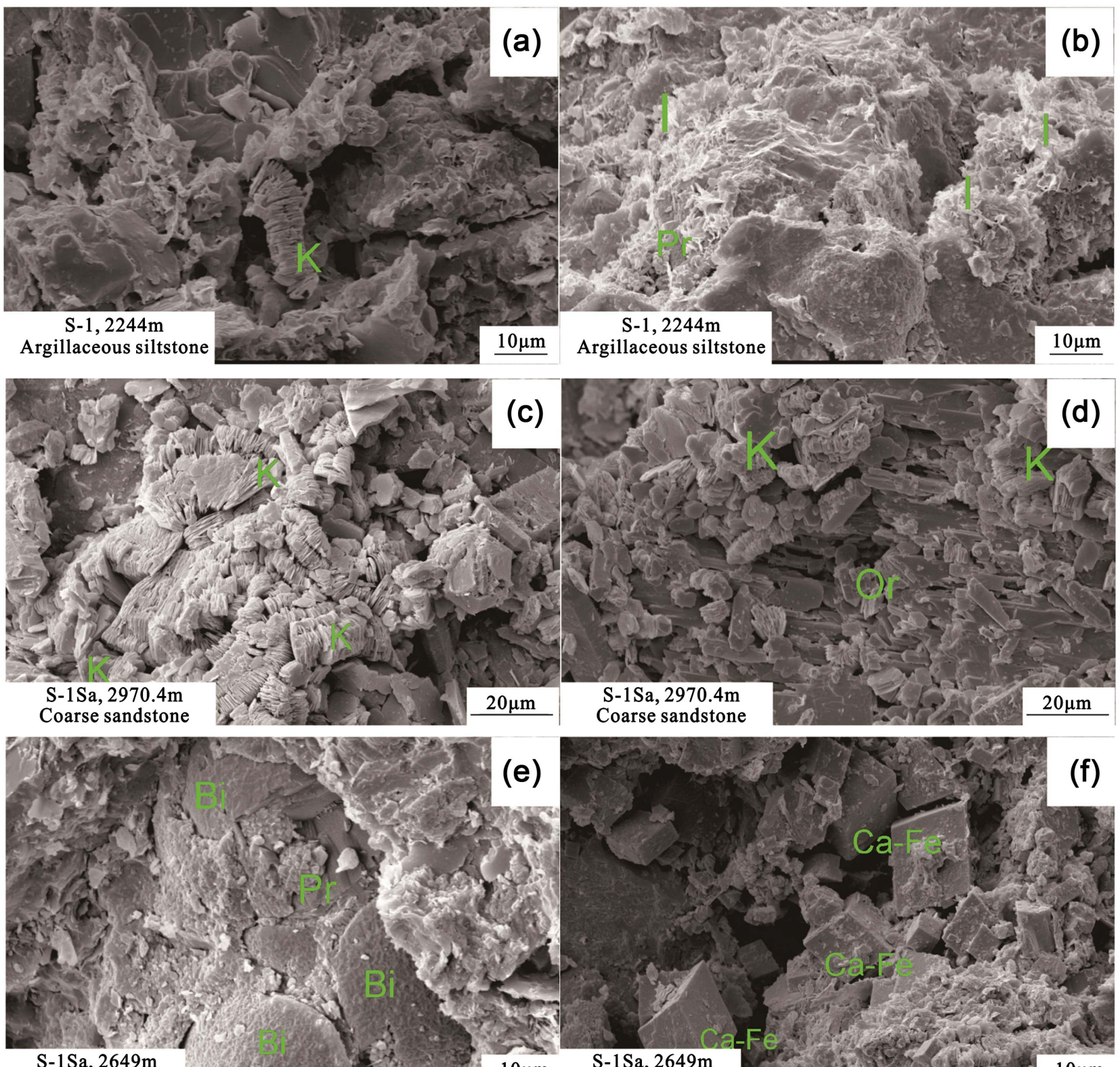

$\mathrm{S}-1 \mathrm{Sa}, 2649 \mathrm{~m}$ Gray fine sandstone

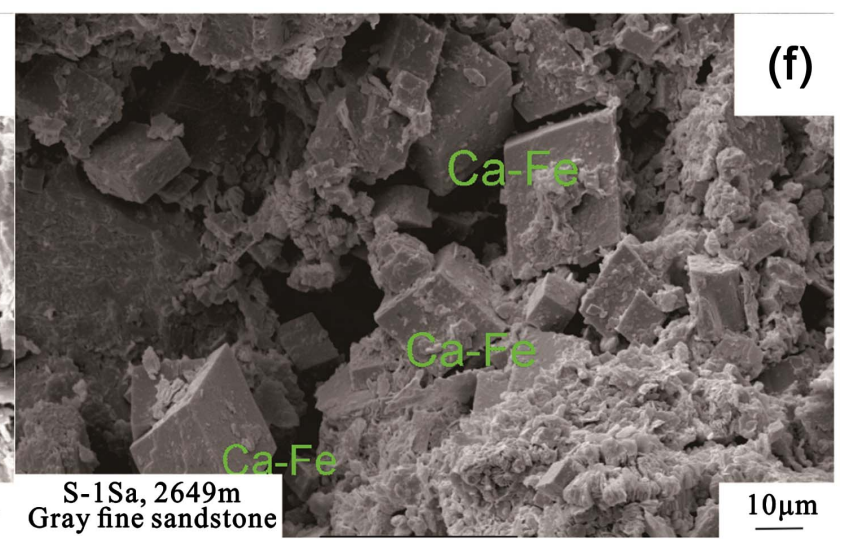

Figure 12. Pore space comparation between calcareous interbed and sandstone reservoirs in scanning electron microscope: (a) Kaolinite filling in intergranular pores; (b) Pyrite and illite gather around particles; (c) Circumgranular Kaolinite; (d) Dramatically eroded K-feldspar and kaolinite on its surface; (e) Bioclastic grains; (f) Iron calcite filling in intergranular pores. 
According to the stratigraphic thickness figure and drilling analysis, calcareous interbeds mostly develop in the paleo-tectonic highs (Figure 13). In view of the above, it is speculated that calcareous interbeds in Songtao uplift and its periphery mainly distributed on the margin of the sand body with high paleo-tectonics. Therefore, searching for large-scale and high-quality natural gas around without calcareous intercalation in the periphery of $\mathrm{S}$ structure will lay a solid foundation for expanding the scale of reserves.

\section{Conclusions}

1) The lithology of calcareous interlayers in the target area is mainly gray-white, gray-green calcareous medium sandstone and fine sandstone. Calcite, iron dolomite and dolomite are common carbonate cements. Thickness varies from tens of centimeters to several meters, making bubbles in case of acid.

2) The properties of calcareous interlayers in the first member of Sanya formation are poor with low porosity and permeability, taking the form of small pore and throat radius, low degree of their distribution.

3) The electrical characteristics are obvious with low gamma, low acoustic contrast, low neutron, high density together with bright white calcareous nodules or bands in electrical imaging logging.

4) There are two genetic types of calcareous interbed (Type I and Type III). Among them, Type I is formed by the integration of $\mathrm{Ca}^{2+}$ with $\mathrm{CO}_{3}^{2-}$ (calcium debris sediments transformed by fresh water) during the shallow burial stage, usually filling in the primary intergranular pores. While under deep burial conditions, the maturation of organic matter releases a large amount of organic acids, which facilitates the precipitation of calcium carbonate again by increasing the dissolution of carbonate and $\mathrm{pH}$ of the fluid, then Type III comes into being. It's mainly found in interparticle or intragranular dissolved pores or replacing

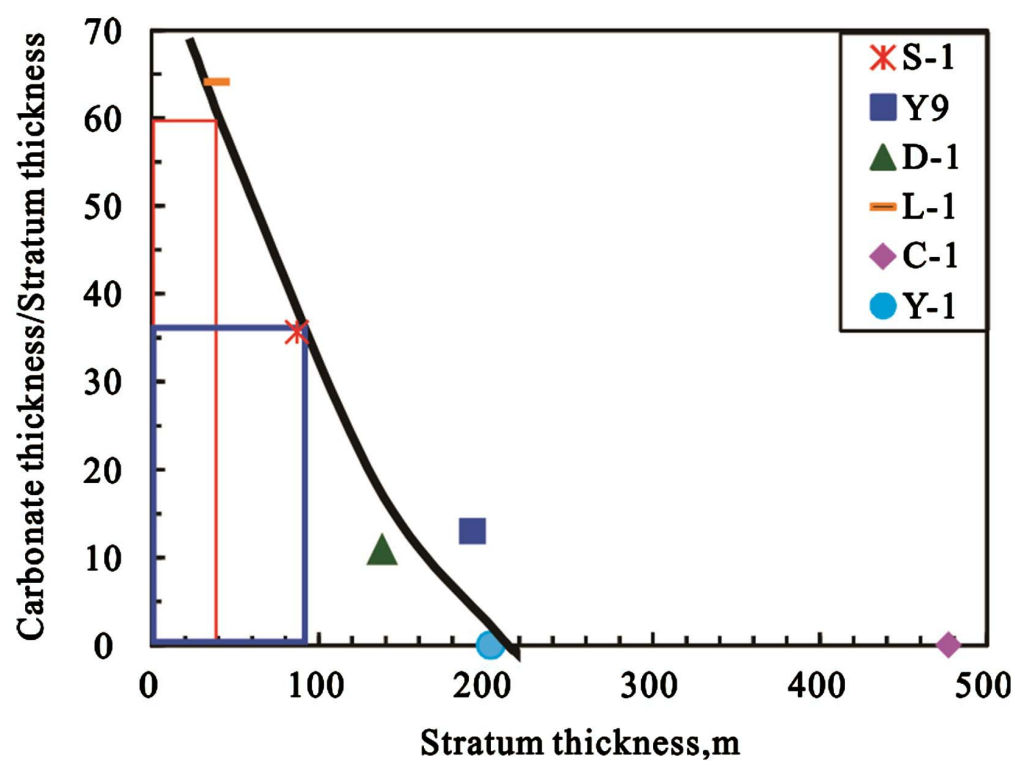

Figure 13. Relationships between carbonate cement content and stratum thickness. 
other particles (such as feldspar).

5) There are four common types of calcareous interbeds as follows: the bottom type, the top type, the central type and the complete type. In general, the bottom type calcareous interbed develops with large thickness, while others widely distribute with low thickness.

6) Calcareous interbed is controlled by both macro and micro aspects. Macroscopically, the distribution is closely related to Paleo-tectonics and sedimentary microfacies. Microscopically, the distribution is affected by the source of material and pore space during carbonate cementation.

7) Based on the evidence presented in this research, Calcareous interlayers mostly develop in high palaeo-structures. Meanwhile, searching for large-scale traps without calcareous interlayers could improve drilling success.

\section{References}

[1] Kantorowicz, J.D., Bryant, I.D. and Dawans, J.M. (1987) Controls on the Geometry and Distribution of Carbonate Cements in Jurassic Sandstones: Bridport Sands, Southern England and Viking Group, Troll Field, Norway. Geological Society, London, Special Publications, 36, 103-118. https://doi.org/10.1144/GSL.SP.1987.036.01.09

[2] Longstaff, F.J. (1981) Clays and the Resource Geology. Mineralogical Association of Canada, United States.

[3] Bjprkum, P.A. and Walder haug, O. (1990) Geometrical Arrangement of Calcite Cementation within Shallow Marine Sandstones. Earth Science Reviews, 29, 145-161. https://doi.org/10.1016/0012-8252(0)90033-R

[4] Chowdhury, A.H. and Noble, J.P.A. (1996) Origin, Distribution and Significance of Carbonate Cements in the Albert Formation Reservoir Sandstones, New Brunswick, Canada. Marine and Petroleum Geology, 13, 837-846. https://doi.org/10.1016/0264-8172(96)00002-5

[5] Xu, B.-M. and Lu, B. (1994) The Study of Diagenetic Carbonate in Siliciclastic Rock and Its Controlling on Reservoirs. Acta Sedimentologica Sinica, 12, 56-66.

[6] Huang, S.-J., Wu, W.-H., Liu, J., Shen, L.-C. and Huang, C.-G. (2003) Generation of Secondary Porosity by Meteoric Water during Time of Subaerial Exposure: An Example from Yanchang Formation Sandstone of Triassic of Ordos Basin. Earth Science-Journal of China University of Geosciences, 28, 419-424.

[7] Lin, C.-Y., Hou, L.-H., Dong, C.-M., Liu, Z.-R., Xin, Q.-L. and Huang, J.-Z. (1996) Study on Calcareous Interbeds in Turbidite Reservoir of Sha 3 Member of the Liaohe Western Depression. Acta Sedimentologica Sinica, 14, 72-80.

[8] Shan, J.-F., Zhao, Z.-J., Li, F.-P., Cheng, D. and Wang, B. (2015) Mechanism and Controlling Factors of Calcium Interbeds Formed in Reservoir. Geological Review, 61, 614-620.

[9] Taylor, K.G., Gawthorpe, R.L., Curtis, C.D., et al. (2000) Carbonate Cementation in a Sequence-Stratigraphic Framework: Upper Cretaceous Sandstones, Book Cliffs, Utah Colorada. Journal of Sedimentary Research, 70, 360-372. https://doi.org/10.1306/2DC40916-0E47-11D7-8643000102C1865D

[10] Jiang, H., Wang, H., Xiao, J., Lin, Z.-L. and Cai, J. (2009) Prospective Zone Prediction by Palaeogeomorphology Analysis Method-Taking No2 Fault Zone in Qiongdongnan Basin as an Example. Petroleum Exploration and Development, 36, 
436-441.

[11] Lei, C., Ren, J.Y., Li, X.S., Tong, C.X., Yin, X.Y. and Min, H. (2011) Structural Characteristics and Petroleum Exploration Potential in the Deep-Water Area of the Qiongdongnan Basin, South China Sea. Petroleum Exploration and Development, 38, 560-569.

[12] Hendry, J.P., Wilkinson, M., Fallick, A.E. and Haszeldine, R.S. (2000) Ankerite Cementation in Deeply Buried Jurassic Sandstone Reservoirs of the Central North Sea. Journal of Sedimentary Research, 70, 227-239. https://doi.org/10.1306/2DC4090D-0E47-11D7-8643000102C1865D

[13] Fayek, M., Harrison, T.M., Grove, M., Mckeegan, K.D., et al. (2001) In Situ Stable Isotopic Evidence for Protracted and Complex Carbonate Cementation in a Petroleum Reservoir, North Coles Levee, San Joaquin Basin, California, USA. Journal of Sedimentary Research, 71, 444-458. https://doi.org/10.1306/2DC40954-0E47-11D7-8643000102C1865D

[14] Keith, M.L. and Weber, J.N. (1964) Carbon and Oxygen Isotopic Composition of Selected Limestones and Fossils. Geochimica et Cosmochimica Acta, 28, 1786-1816.

[15] Wang, C.-S., Chen, X.-H. and Wang, X.-F. Oxygen Isotope Characteristics and Pale Seawater Temperature Analysis of Triassic Xiaoao Member in Guanling Area.

[16] Wang, S.-C., Wang, X.-F., Chen, X.-H. and Li, Z.-H. (2009) The SST Change and Its Influence on the Distribution of Graptolite Fauna-An Example from the Ordovician Dawan Formation in Yichang Hubei Province. Acta Geologica Sinica, 83, 751-758.

[17] Wang, Z.-H. and Zhang, S.-J. (1998) Discovery and Characteristics of High Mineralized Soda-Dicarbonate Typed Water in Karamay Oil Region. Experimental Petroleum Geology, 20, 39-43.

[18] Liu, Y.-Q., Zeng, J.-H., Zhou, L. and Zhai, S.-J. (2013) Geochemical Characteristics and Origin of Shahejie Formation Water in Huimin Sag. Geoscience, 27, 1110-1119.

[19] Guo, H.-L. and Wang, D.-R. (1999) Stable Isotopic Composition and Origin Analysis of the Carbonate Cements within Sandstone Reservoirs of Tarim Oilgas Bearing Area. Research Institute of Petroleum Exploration and Development, 26, 31-32.

[20] Liu, L., Bao, Z.-D., Qin, Z., Fan, Z.-P., Lin, Y.-B., Deng, X.-L. and An, K.-S. (2016) Controlling Factors of Calcareous Interlayers Distribution in Ultra-Low Permeability Reservoirs: Micro Evidence from Petrology and Diagenesis. Natural Gas Geoscience, 27, 1035-1045.

[21] Wang, Q.-B., Zang, C.-Y., Lai, W.-C., Wang, B., Wang, X.-L. and Zhao, X.-J. (2009) Distribution Characteristics and Origin of Carbonate Cements in the Middle and Deep Clastic Reservoirs of the Paleogene in Bozhong Depression. Oil \& Gas Geology, 30, 438-443.

[22] Xin, Y.-F. and Li, H.-Q. (2005) Origin of Calcareous Interbeds and Its Significance of Sequence Stratigraphy in Junggar Basin. Acta Petrolei Sinica, 26, 24-31.

[23] Tian, Y., Lu, Z.-S., Quan, Y.-Z., Si, Y., Zhang, H.-C. and Peng, S. (2009) Calcareous Interbeds in the Sandstone Reservoir of Shen-95 Block with in Damintun Sag Liaohe Basin. Acta Petrologica et Mineralogica, 28, 152-160.

[24] Pu, Y., Wang, W. and Li, C.Y. (2016) Features and Genesis of Calcareous Interbeds in Tight Sandstone, Xujiahe 4 Member, Bazhong Area. Natural Gas Technology and Economy, 10, 16-20.

[25] Sun, Z.-X., Sun, Z.-L., Lu, H.-J. and Yin, X.-J. (2010) Characteristics of Carbonate Cements in Sandstone Reservoirs: A Case from Yanchang Formation, Middle and 
Southern Ordos Basin, China. Petroleum Exploration and Development, 37, 543-551. https://doi.org/10.1016/S1876-3804(10)60054-7

[26] Zhang, M.-Q., Huang, S.-J., Wu, Z.-X. and Hu, Z.-W. (2007) Carbonate Cements and Their Formation Mechanism in Palaeogene Sandstones of Lishui Sag, East China Sea Basin. Journal of Chengdu University of Technology (Science \& Technology Edition), 34, 259-266.

[27] Wang, F.-R., He, S., He, Z.-L., et al. (2009) Carbonate Cements Features and Its Genetic Significance of Sandstones in Yongjin Area of Junggar Basin. Acta Petrologica et Mineralogica, 28, 169-178.

[28] Zhang, Y.-W., Zeng, J.-H., Gao, X. and Zhou, S.-Y. (2009) Distribution Characteristics and Main Controlling Factors of Carbonate Cements in the Paleogene Reservoirs in Dongying Depression. Journal of Jilin University (Earth Science Edition), 39, 16-22.

[29] Qi, B.-W., Lin, C.-M., Qiu, G.-Q., Li, Y.-L., Liu, H.-M. and Gao, Y.-J. (2006) Formation Mechanism of Calcareous Incrustation in Lenticular Sandbody of the Shahejie Formation of Paleogene and Its Influence on Hydrocarbon Accumulation in Dongying Sag. Journal of Palaeogeography, 8, 519-530.

[30] Zeng, J.-H., Peng, J.-L., Qiu, N.-S. and Zhu, Z.-Q. (2006) Carbonate Dissolution Precipitation in Sandstone-Shale Contact and Its Petroleum Geological Meanings. Natural Gas Geoscience, 17, 760-764.

[31] Zhong, D.-K., Zhu, X.-M. and Zhang, Q. (2004) Variation Characteristics of Sandstone Reservoirs when Sandstone and Mudstone Are Interbedded at Different Buried Depths. Acta Geologica Sinica, 78, 864-869.

[32] Song, H.-L., Hong, B.-G., Zhang, Y.-C., et al. (2013) Study on Genesis and Distribution of Paleogene Calcareous Sandstone in Liaodong Gulf, Bohai Sea-Case of 3rd Member of Shahejie Formation in Well Area 3 of Jinzhou 25-1 Oilfield. Petroleum Geology and Recovery Efficiency, 20, 55-59. 